\title{
Intradermalinjection of Bothrops cotiara venom in mice in an experimental wound model
}

Lopes JA (1), Giménez APL (1), Zischler LFCM (1), Stuelp-Campelo PM (1), Moreno AN (1), ElifioEsposito SL $(1,2)$

(1) Laboratory of Experimental Biology, Pontifical Catholic University of Paraná (PUCPR), Curitiba, Paraná State, Brazil; (2) Group for Advanced Molecular Investigation (NIMA), PPGCS/CCBS, Pontifical Catholic University of Paraná (PUCPR), Curitiba, Paraná State, Brazil.

\begin{abstract}
Bothropic envenomation induces hemorrhage, coagulant disturbances and necrosis. Regarding therapies against the local damage caused by the venom, there is little information on tissue changes until the complete healing. In the current study, local damage was evaluated by examination of morphological inflammatory alterations, mast cell count, and analysis of collagen deposition. Bleeding was evident four hours after inoculation. After 24 hours, a large area of injury appeared presenting disorganized tissue, significant hemorrhage and acute inflammation. After three days, the damaged area was extensive, with a large amount of inflammatory cells and the presence of scab. In seven days, healing and reepithelization process started. And, 21 days later, the epithelium showed less infiltration and no skin appendages. The number of mast cells was similar to control after four hours, with a drop of $50 \%$ at 24 hours, followed by an increase until the $21^{\text {st }}$ day. No differences of collagen deposition were observed among experimental groups. Taken together, wound healing after intradermal injection of Bothrops cotiara venom in mice follows similar parameters to wounds caused by other bothropic venoms. The present work reveals the importance of experimental wound models to the study of neutralizing agents against venom toxins.
\end{abstract}

Key words: Bothrops venom, wound healing, inflammation, local damage.

\section{INTRODUCTION}

Accidents caused by venomous snakes represent a significant public health problem, particularly in tropical countries where the frequency of occurrence of such events as well as morbidity and mortality rates are higher (1, 2). The genus Bothrops (Viperidae) comprises about 30 species distributed throughout Brazil and is responsible for $90 \%$ of accidents in South America (3, 4).

Bothrops cotiara is a terrestrial species, whose venom, like other species of the genus, causes inflammation (edema and erythema), bruising, blisters, and necrosis at the bite site (5). The early administration of antibothropic serum
( $A B$ serum) or antibothropic-crotalic serum ( $\mathrm{ABC}$ serum) after the bite is the only treatment available and accepted by the Brazilian Health System, which leads to a low mortality in treated cases $(0.3 \%)$ when routine conditions of care are followed. However, the serum only partially neutralizes the local effects caused by the venom and patients may present sequelae such as total or partial loss of the affected limb (6).

The use of plant extracts as antidotes for animal venoms is a traditional option still employed in many parts of the globe, particularly in those where the access to antivenom therapy is not immediate $(7,8)$. The application of such antidotes in palliative care against the effects of toxins from snake venoms, however, still requires 
clinical validation and accurate description of tissue processes involved in the neutralization induced by these extracts.

The necrotizing action of the venom derives from the direct cytotoxic effect of its proteolytic fractions that provoke local lesions. Nevertheless, vascular and coagulant effects may also contribute to the onset of such lesions. Local necrosis may be complicated by infection with bacteria (especially those from the mouth of the snake), abscess formation (that causes dystrophies) and sequelae of poor healing (5, 9-11). Important advances have been made toward understanding the pathogenesis of hemorrhage and myonecrosis in viperid snakebite envenomation $(9,12,13)$. However, the study of pathological alterations induced by these venoms in the skin has received little attention, despite its clinical relevance (14).

This work shows the macroscopic and histological changes at the site of Bothrops cotiara venom injection through complete healing. Further comprehension of the progression of tissue injury and repair may help in understanding the mechanisms of natural agents used to prevent the severe necrosis or to heal the affected tissue.

\section{MATERIALS AND METHODS}

\section{Biological Material}

Bothrops cotiara venom was kindly provided by the Butantan Institute, SP, Brazil, as a lyophilized pool. Mice (Mus musculus, Swiss strain) were maintained at the animal facility of the Pontifical Catholic University of Paraná (PUCPR), under controlled conditions of temperature and humidity for a photoperiod of 12 hours and in an ad libitum supply of food and water. This project was submitted and approved by the Ethics Committee For Animal Use of PUCPR (protocol n. 196/07) and followed the ethical standards of animal experimentation.

\section{Experimental Protocol}

The minimum necrotizing dose (MND) is defined as the minimum dose of venom capable of causing a $1-\mathrm{cm}^{2}$ area of necrosis (15). Crude venom solutions of 50 to $300 \mu \mathrm{g}$ in $50 \mu \mathrm{L}$ were tested previously and MND was defined as 100 $\mu \mathrm{g}$. Eight-week old mice ( $40 \mathrm{~g}$ ) were anesthetized by intraperitoneal (IP) injection of sodium thiopental $(40 \mathrm{mg} / \mathrm{kg})$ and the dorsal area between the hind limbs was shaved for venom application at the MND $(2.5 \mathrm{mg} / \mathrm{kg})$ by intradermal (ID) injection. Control groups received $0.9 \% \mathrm{NaCl}$ solution. At different times after inoculation (4 and 24 hours; 3, 7, 14 and 21 days) the animals were euthanized by IP administration of a single dose of sodium thiopental $(100 \mathrm{mg} / \mathrm{kg})$. Each experimental group $(n=6)$ was compared to the control group $(n=4)$ that corresponded to the time of observation after inoculation.

\section{Macroscopic Evaluation}

After the animals were sacrificed the outer skin surface was examined and photographed. The mean area of necrosis was determined by measuring the edges of the lesion in digital photographs using ImagePro Plus software for Windows (Media Cybernetics, USA). A $1-\mathrm{cm}^{2}$ paper square was added to the photographed field as a reference measure and the area of necrosis in each tissue was calculated proportionally to the reference measure.

\section{Histological Procedures}

Skin tissue of mice was removed and fixed in $10 \%$ formalin. The samples were then dehydrated, cleared, impregnated with liquid paraffin, and cut in microtome. The sections were stained with hematoxylin-eosin, trichome of picrosirius, and toluidine blue. Images were obtained with a Leica DMBL microscope (Leica Microsystems, Germany) and captured with a Digital Microscope Camera (Polaroid). Quantifications were obtained with the ImagePro Plus Software (Media Cybernetics, USA).

The analysis of tissue changes and counting of mononuclear and polymorphonuclear inflammatory infiltrate were performed on slides stained with hematoxylin and eosin. Cell counting was made only in sections where an infiltrate was visible in three random fields right below the lesion or the scab, when present.

Images from toluidine blue-stained sections were used for mast cells counting. Four random fields (magnitude: 400x), from four different areas of the skin, were analyzed, totaling 16 fields per animal. Additional sections were stained with Picrosirius Red (Sigma, USA) and examined using cross-polarization optics to evaluate the nature of collagen fibers (16).

When Sirius red reacts with collagen, the different collagen fiber types stain from greenish yellow to yellowish orange to orange. Collagen 
type I stains yellow or red, whereas collagen type III stains green. The quantification of the percentage of collagens according to their coloration allows qualitative evaluation of collagen deposition. The software ImagePro Plus (Media Cybernetics, USA) was used to determine the percentage area occupied by each collagen type (17). The quantification of collagen fibers was done on images taken at a 200x magnification. After sectioning four different areas of the skin, three random fields were analyzed, totaling 12 fields per animal. Considering that collagen deposition occurs from the fifth day after skin injury, only the sections from groups 7,14 and 21 days were analyzed.

\section{Statistical Analysis}

All results were reported as means \pm standard error of the mean. Analysis of variance (ANOVA) was used to compare treatment group means. The Tukey's test was used to determine if treated animals were significantly different when compared to untreated animals. Values of $\mathrm{p}$ less than 0.05 were regarded as statistically significant.

\section{RESULTS}

Intradermal injection of the venom of B. cotiara in mice resulted in acute damage to the skin by provoking hemorrhage that was noticeable a few minutes after the inoculation, dermonecrosis and blistering. Measurements of the lesion areas for experimental and control groups are shown in Figure 1. A gradual increase in the injured area was seen up to the third day after venom administration, followed by a decrease until the apparent healing after 21 days. Representative histological sections of each group show the progression of the injury development until wound healing (Figure 2).

Control groups of all time periods showed no tissue damage, edema, infiltration nor abnormality in the epidermis, dermis, or muscle tissue. Four hours after inoculation of the venom the epithelial and connective tissues remained unaltered; however, bleeding was evident. After 24 hours, a large area of injury was perceptible presenting disorganized tissues. It was not possible to distinguish the epithelial and connective tissue region. Many red blood cells were visible revealing a profuse hemorrhage as well as an initial presence of necrotic material covering the most superficial wound. Below, a range of inflammatory cell infiltrates was observed.

After three days, the area of injury was still extensive, but slightly more organized. It was then possible to distinguish the muscle and connective region. A substantial amount of infiltrated inflammatory cells and the presence of scab on the lesion were observed. Red blood cells were still not identified and a layer of adipocytes in the injured tissue intermingled with amorphous tissue was visible. On the seventh day, the lesion site presented a more advanced degree of organization with a wellformed scab on the injured region, presence of inflammatory cell infiltration, appearance of the epithelium at the edges of the lesion below the scab, and more organized connective and muscle tissues.

On the fourteenth day no scab and bleeding were observed. The region of the injury showed signs of repair characterized by epithelialization and an inflammatory infiltrate. After 21 days, the epithelium showed a lower, but still significant, infiltration. No skin appendages such as hair follicles were observed in the healed region.

Polymorphonuclear (PMN) and mononuclear $(\mathrm{MN})$ cells play a key role in regeneration. The result of the cell count is displayed in Figure 3. Twenty-four hours after venom inoculation, a large number of PMN cells were observed. This number decreased gradually up to the $21^{\text {st }}$ day. On the other hand, the MN cell profile showed a small number of cells after 24 hours, increasing up to day 14 , followed by a slight reduction up through the $21^{\text {st }}$ day.

The average number of mast cells in tissues is shown on Figure 4. The cell count was similar to controls after four hours, but showed a decrease of $50 \%$ at 24 hours, followed by a steady increase until the $21^{\text {st }}$ day. The deposition of mature collagen, an important step in the healing process, occured only after the fifth day of injury. Collagen fiber measurement for the examined tissues ( 7,14 and 21 days) showed that the three groups obtained statistically identical results for the quantity of collagen type I and III. Type III collagen was more abundant in all groups. Total collagen (the sum of the two types of collagens analyzed) was also statistically similar between groups (Figure 5). 


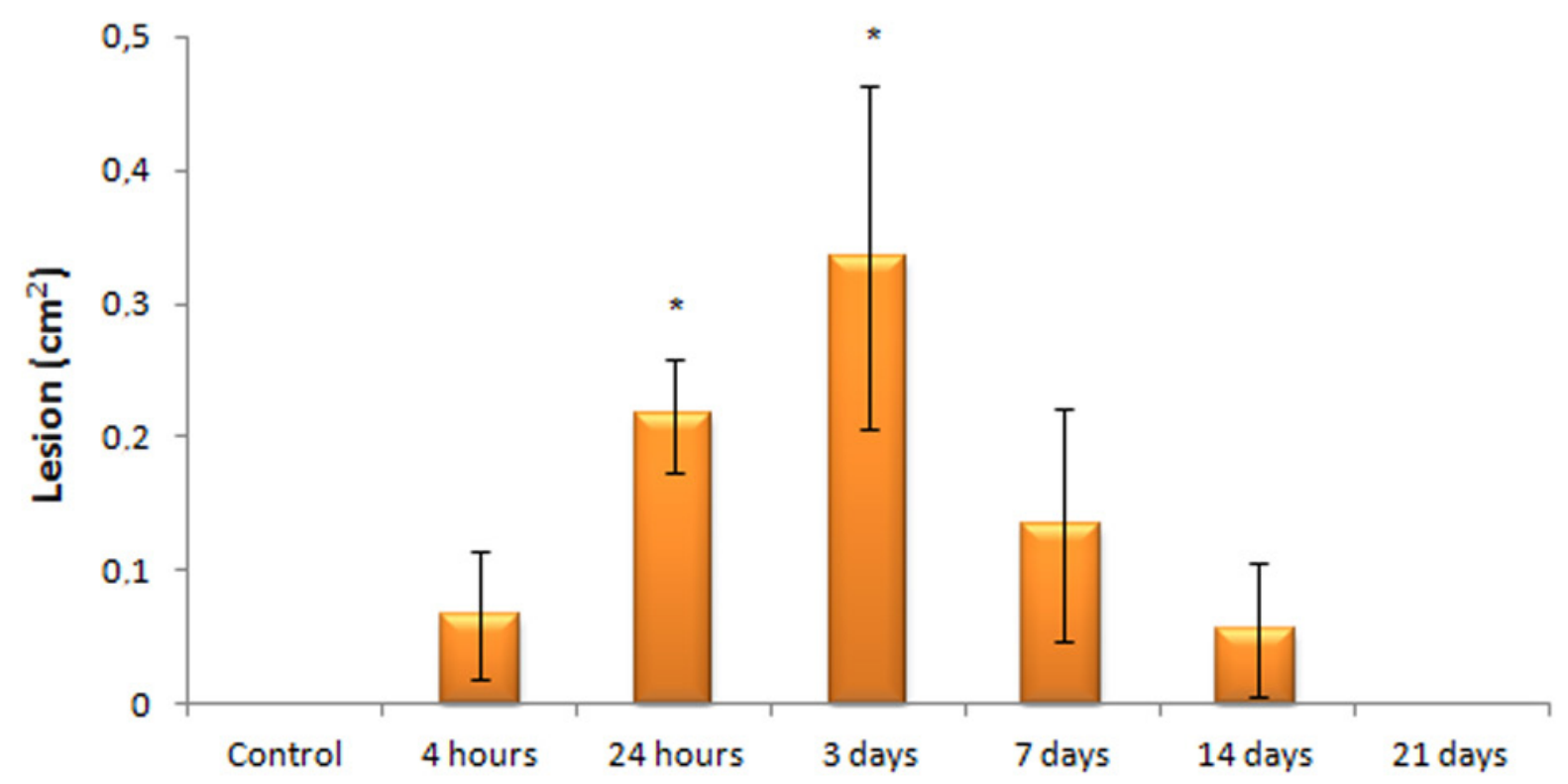

Groups

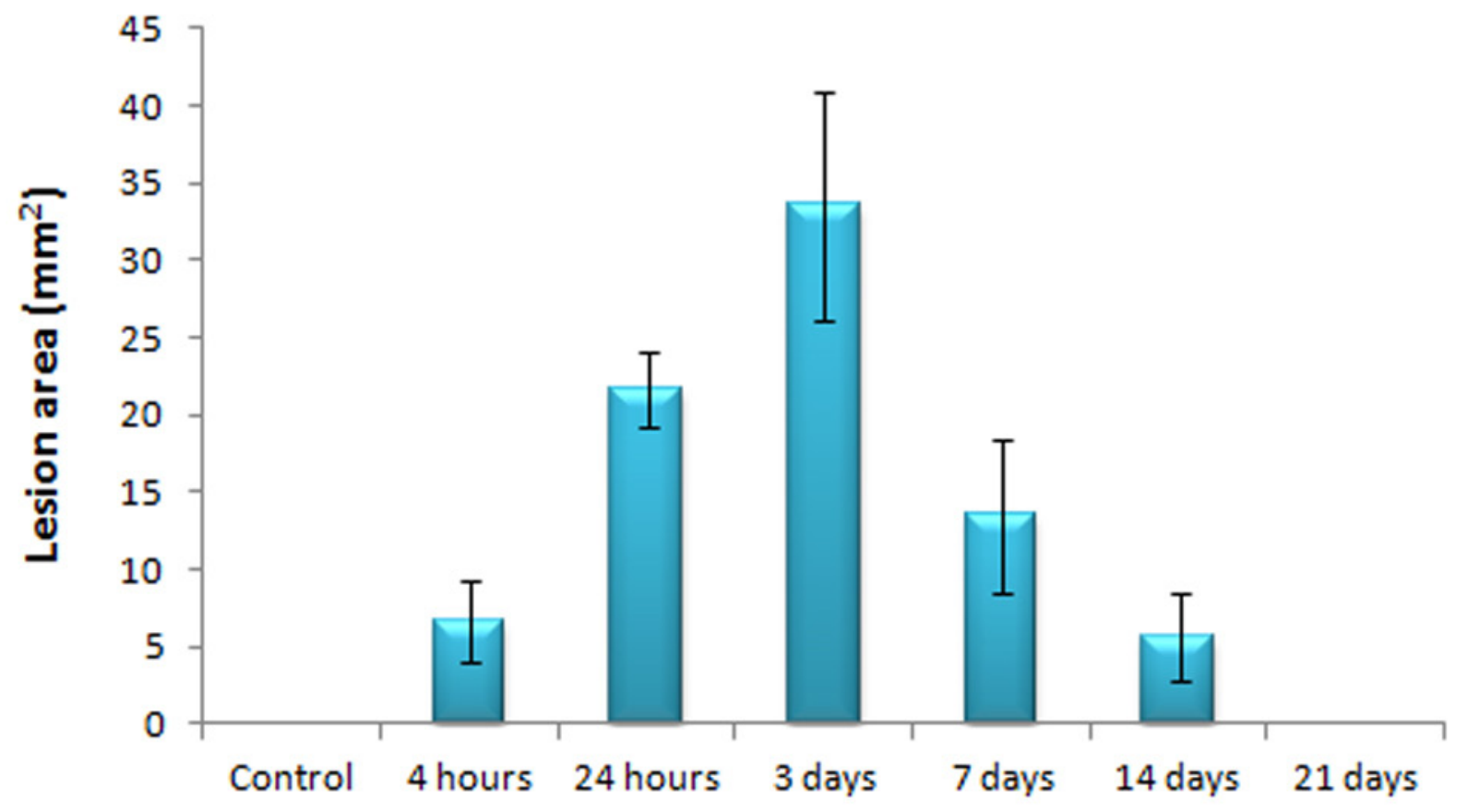

Groups

Figure 1. Lesion area for experimental $(n=6)$ and control $(n=4)$ groups after intradermic injection of Bothrops cotiara venom. Venom $(100 \mu \mathrm{g} / 50 \mu \mathrm{L})$ was injected in the dorsal area between the hind limbs. Control mice received $0.9 \% \mathrm{NaCl}$ solution. At different times after inoculation, the animals were euthanized and the outer skin surface was photographed and measured. Results are represented as mean \pm SEM. *Statistical significance when compared with control group for $p<0.05$. 

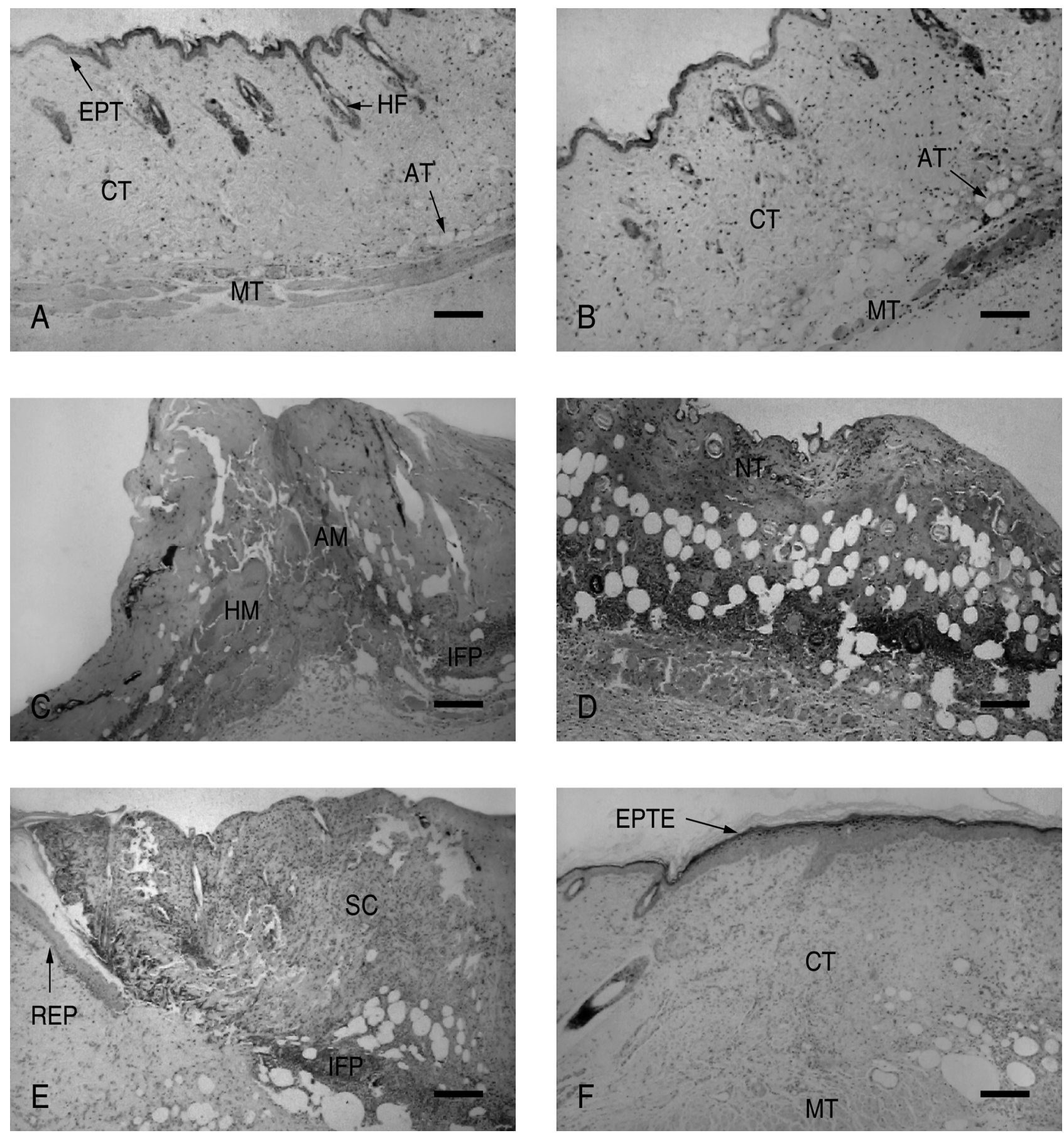

Figure 2. Histological analysis of skin of mice injected with $100 \mu \mathrm{g} / 50 \mu \mathrm{L}$ of Bothrops cotiara venom. Control sites were injected with an equal volume of $0.9 \% \mathrm{NaCl}$ solution. Panels correspond to the panoramic view of HE-stained sections from: (A) control group, (B) four hours after inoculation, (C) 24 hours after inoculation, (D) three days after inoculation, (E) seven days after inoculation, and (F) 21 days after inoculation. HF: hair follicles; AM: amorphous tissue; EPT: epithelial tissue; EPTE: thick epithelial tissue; SC: scab; HM: hemorrhage; IFP: PMN infiltrate; AT: adipose tissue; CT: connective tissue; MT: muscular tissue; NT: necrotic tissue; REP: epithelization area. Bars at the bottom of each panel indicate $250 \mathrm{~mm}$. 


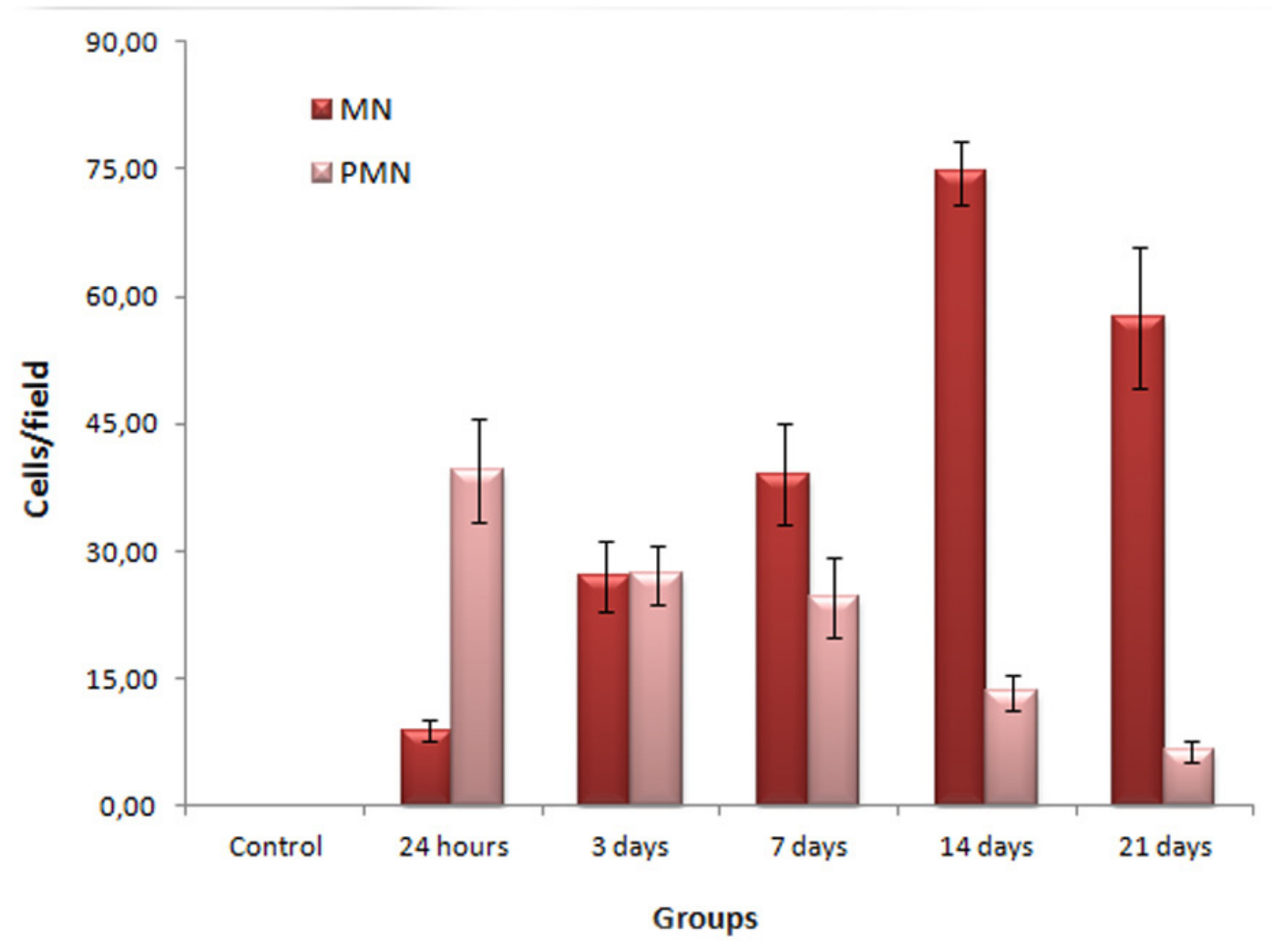

Figure 3. Determination of the number of mono- (MN) and polymorphonuclear (PMN) cells in the skin of mice after injection of Bothrops cotiara venom $(100 \mu \mathrm{g} / 50 \mu \mathrm{L})$ or $0.9 \% \mathrm{NaCl}$ solution (control group). Cell count was performed on histological HE-stained section of lesion areas of the skin where infiltrate was visible. Three random fields per section were analyzed, right below the lesion or the scab (magnitude: 400x). Results are represented as mean \pm SEM.

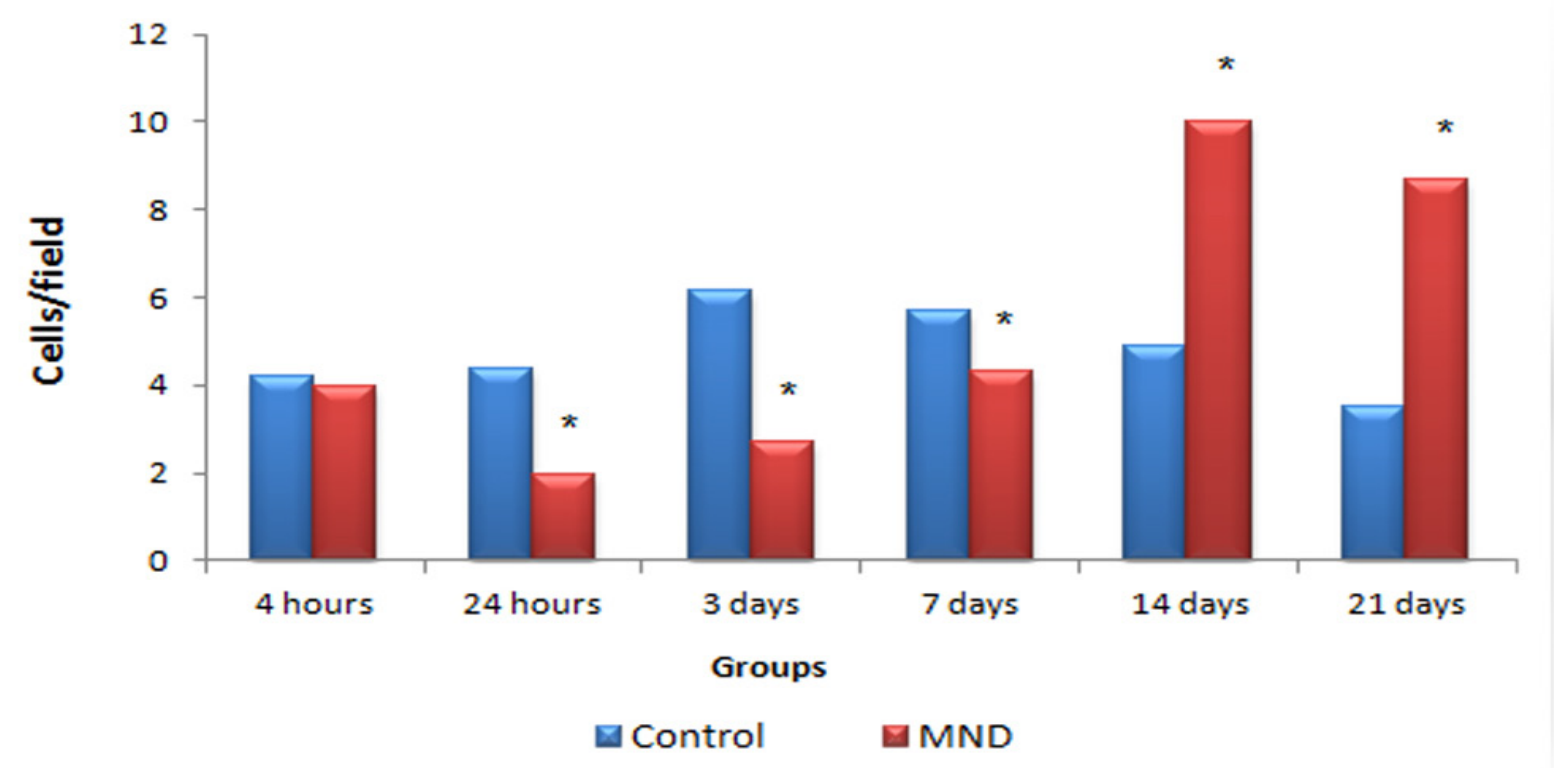

Figure 4. Determination of the number of mast cells in the skin of mice after injection of Bothrops cotiara venom $(100 \mu \mathrm{g} / 50 \mu \mathrm{L}$ ) or $0.9 \% \mathrm{NaCl}$ solution (control group). Cell count was made on toluidin blue-stained section. Four random fields from four different areas of the skin were analyzed in a magnitude of 400x, totaling 16 fields per animal. To obtain the values on the chart, the number of cells found in control groups for each time was subtracted from the total cells found in the sections from experimental groups of the same treatment time. *Statistical significance when compared with control group for $p<0.05$. MND: minimum necrotizing dose. 


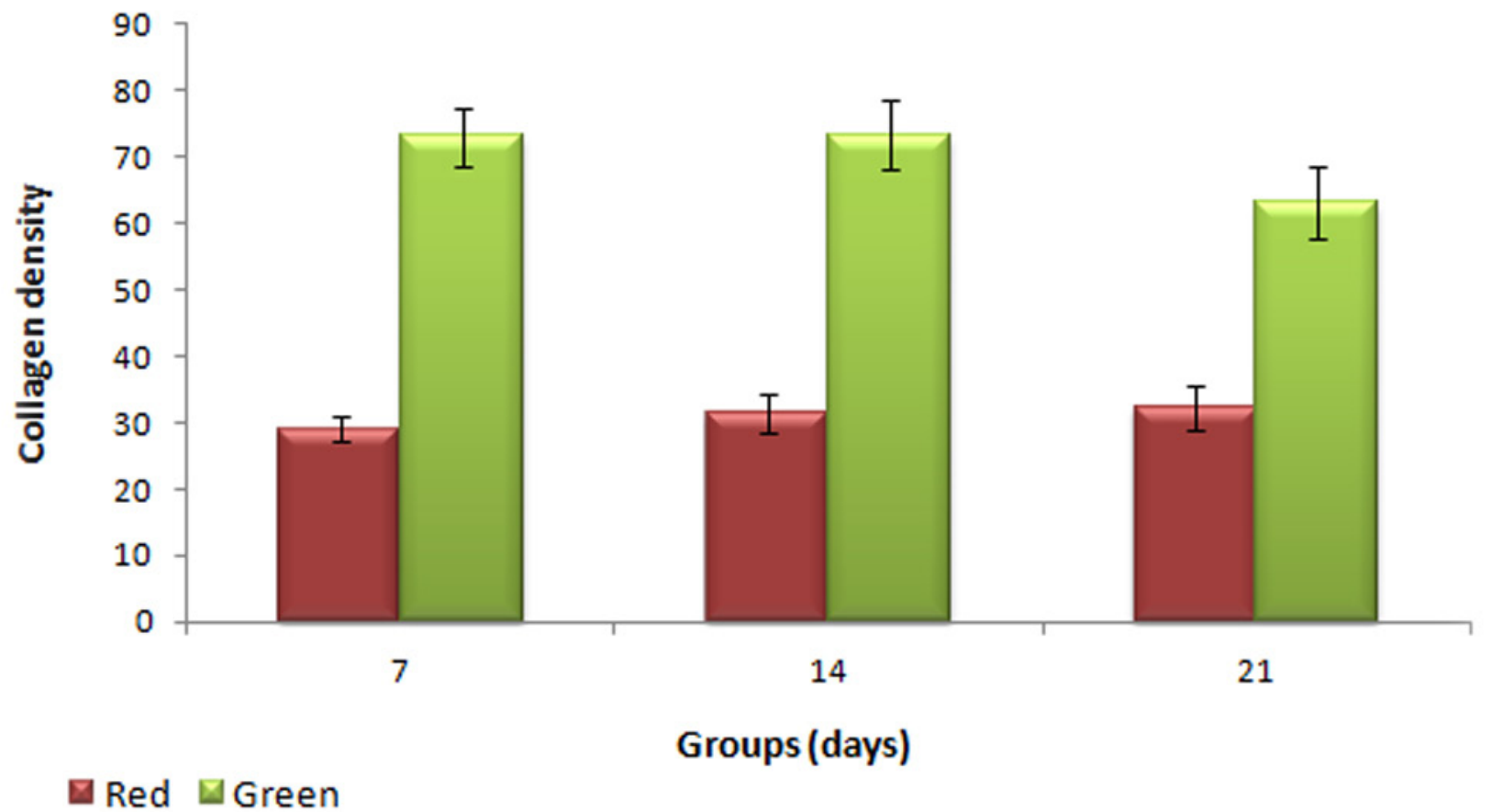

Figure 5. Qualitative evaluation of collagen deposition in the skin of mice after injection of Bothrops cotiara venom $(100 \mu \mathrm{g} / 50 \mu \mathrm{L})$ or $0.9 \% \mathrm{NaCl}$ solution. Type I (yellowish-red) and III (green) collagen on histological sections of the skin stained with picrosirius red were examined using cross-polarization optics. The quantification of the collagen fibers density per section was done on images taken at 200x magnification, according to their coloration, using the software ImagePro Plus. Three random fields in four different areas of the skin were analyzed, totaling 12 fields per animal. Results are represented as mean \pm SEM. *Statistical significance when compared with control group for $p<0.05$.

\section{DISCUSSION}

Healing is a response to tissue destruction that includes the process of regeneration and repair by the replacement of damaged cells by fibrous tissue. The stages related to the healing include inflammation, proliferation and maturation, phenomena that occur simultaneously $(18,19)$. In the current study, the inflammatory infiltrate, characterized by PMN leukocytes, peaked on the third day. From the seventh day on, the number of cells began to decrease, which led to a reduction of edema, hemorrhage, necrosis and inflammation composed primarily of MMN cells, characterized mainly by macrophages, and multifocal inflammatory infiltration with PMN cells. This activity represents a characteristic progression of cellular events in response to local damage, regardless of the type of wound. Within hours after the initial injury of the tissue, PMN cells migrate to the site, followed by MMN cells that progressively migrate to the wound and increase in number, whereas PMN cells begin to decline within 48 to 72 hours (20).

The tissue damage caused by Bothrops venoms is a result of enzyme action, particularly proteases and phospholipases, which cause lesions on small blood vessel walls, bleeding, ischemia, and edema or even cell damage by direct disruption of the plasma membrane $(9,21-23)$. In the present study, Bothrops cotiara venom generated a kinetic action on the skin that followed the healing stages mentioned. Hemorrhage appeared a few minutes after venom inoculation. After 24 hours, histological sections of the affected site showed a large area of injury with disorganized tissues, major bleeding and initial presence of necrotic material covering the most superficial wound. Hemorrhage and necrosis persisted until the third day, on which the framework of healing and tissue regeneration began to occur.

Since in acute inflammatory reactions several 
of the changes in leukocyte recruitment and vascular characteristics reflect, at least in part, in the release of chemical mediators from injured tissue, mast cells have historically been considered important potential agents in the initiation and/ or amplification of the inflammatory response. Cutaneous inflammatory responses against allergens or autoantigens, for example, are also associated with the activation of mast cells and their release of proinflammatory mediators.

This is not surprising since large numbers of mast cells are expressed in the skin, where they represent 2 to $8 \%$ of dermal cells and are distributed primarily in the vicinity of the epidermis, hair follicles, blood vessels, and nerves (24). Their main function is to store potent chemical mediators of inflammation in cytoplasmic granules that are released on cell activation, which can be triggered by different immunological or non-immunological stimuli, such as physical agents or toxins from bee or snake venoms $(25,26)$. Even though skin mast cells are thought to promote resistance to ticks, control hair growth, and induce foreign body granuloma formation, their role and functional relevance in cutaneous physiology still remains unclear (27-31).

The findings of this study have shown that the presence of acute inflammatory infiltrate diminished the population of mast cells in the injured region. Meanwhile, in the healing phase, the population gradually increased, doubled in comparison to controls. A possible assumption is that mast cells can increase the population immediately after venom application. Considering that the toluidine blue dye stained the granules, we suggest that the degranulation made them undetectable by this method. In the analysis of the slides, we observed that for later groups, for which the number of mast cells began to increase (7 and 14 days), the coloring was lighter, and fewer granules were present, thus suggesting that the population increased in number from 24 hours on; however, could not be counted. Upon regranulation, the count appears to increase.

Fibroblasts have several stages of maturity, producing collagen that accumulates as connective tissue for reepithelialization (21). Fibrillar collagens are an important part of the connective tissue at the site of repair and are important in the development of resistance in wound healing.
The synthesis of collagen by fibroblasts begins at a relatively early phase (within 3 to 5 days) and continues for several weeks depending on the wound $(32,33)$. Considering that type III collagen is related to scar maturation and was more abundantly found, we can assume that the fibroplastic changes in the present study were in a good state of evolution; however, it should progress for an even longer time period.

The macroscopic and microscopic analysis of mouse skin after intradermic injection of Bothrops cotiara venom demonstrated a sequence of events characteristic of tissue injury and regeneration, suggesting the value of utilizing crude venom for the production of experimental wounds in order to study neutralizing extracts of venom toxins or other healing agents.

\section{ACKNOWLEDGMENTS}

The authors thank Dr. Lucia de Noronha, Ana Paula Camargo Martins and the entire staff of the Laboratory of Experimental Pathology of PUCPR for the histological preparations; Dr. Antonio Adilson de Lima for his helpful advice and comments; Butantan Institute, SP, Brazil, for providing the Bothrops cotiara venom; and to the team of the animal facility of PUCPR.

\section{COPYRIGHT}

(C) CEVAP 2012

\section{SUBMISSION STATUS}

Received: June 28, 2011.

Accepted: November 23, 2011.

Abstract published online: November 28, 2011.

Full paper published online: February 28, 2012.

\section{CONFLICTS OF INTEREST}

The authors declare no conflicts of interest.

\section{FINANCIAL SOURCE}

The Araucária Foundation from Paraná state, Brazil, provided the financial grants.

\section{ETHICS COMMITTEE APPROVAL}

The present study was approved by the Ethics Committee for Animal Use of Pontifical Catholic University of Paraná (PUCPR), Paraná state, Brazil, under protocol n. 196/07, and followed the national ethical standards for animal experimentation. 


\section{CORRESPONDENCE TO}

Selene Lobo Elifio-Esposito, Centro de Ciências Biológicas e da Saúde, Programa de Pósgraduação em Ciências da Saúde, Pontifícia Universidade Católica do Paraná, Curitiba, PR, 80215-901, Brasil. Phone: +55 4132712282. Email: selene.e@pucpr.br.

\section{REFERENCES}

1. Gutiérrez JM, Theakston RD, Warrell DA. Confronting the neglected problem of snake bite envenoming: the need for a global partnership. PLoS Med. 2006;3(6):e150.

2. Chippaux JP. Snake-bites: appraisal of the global situation. Bull World Health Organ. 1998;76(5):51524.

3. Bochner R, Struchiner CJ. Snake bite epidemiology in the last 100 years in Brazil: a review. Cad Saude Publica. 2003;19(1):7-16.

4. Lima JS, Martelli Júnior H, Martelli DR, Silva MS, Carvalho SF, Canela JR, et al. Profile of snakebite accidents in the north of the State of Minas Gerais, Brazil. Rev Soc Bras Med Trop. 2009;42(5):561-4.

5. Jorge MT, Ribeiro LA, da Silva ML, Kusano EJ, de Mendonca JS. Microbiological studies of abscesses complicating Bothrops snakebite in humans: a prospective study. Toxicon. 1994;32(6):743-8.

6. Mors WB, Nascimento MC, Pereira BM, Pereira NA. Plant natural products active against snake bite - the molecular approach. Phytochemistry. 2000;55(6):62742.

7. Biondo R, Pereira AM, Marcussi S, Pereira PS, Franca SC, Soares AM. Inhibition of enzymatic and pharmacological activities of some snake venoms and toxins by Mandevilla velutina (Apocynaceae) aqueous extract. Biochimie. 2003;85(10):1017-25.

8. Pithayanukul P, Laovachirasuwan S, Bavovada R, Pakmanee N, Suttisri R. Anti-venom potential of butanolic extract of Eclipta prostrata against Malayan pit viper venom. J Ethnopharmacol. 2004;90(2-3):34752.

9. Gutiérrez JM, Rucavado A, Chaves F, Díaz C, Escalante T. Experimental pathology of local tissue damage induced by Bothrops asper snake venom. Toxicon. 2009;54(7):958-75.

10. Lomonte B, Gutiérrez JM, Furtado MF, Otero R, Rosso JP, Vargas $\mathrm{O}$, et al. Isolation of basic myotoxins from Bothrops moojeni and Bothrops atrox snake venoms. Toxicon. 1990;28(10):1137-46.

11. Selistre HS, Queiroz LS, Cunha OA, De Souza GE, Giglio JR. Isolation and characterization of hemorrhagic, myonecrotic and edema-inducing toxins from Bothrops insularis (jararaca ilhoa) snake venom. Toxicon. 1990;28(3):261-73.

12. Gutiérrez JM, Ownby CL. Skeletal muscle degeneration induced by venom phospholipases A2: insights into the mechanisms of local and systemic myotoxicity. Toxicon. 2003;42(8):915-31.

13. Fox JW, Serrano SM. Structural considerations of the snake venom metalloproteinases, key members of the M12 reprolysin family of metalloproteinases. Toxicon. 2005;45(8):969-85.

14. Jiménez N, Escalante T, Gutiérrez JM, Rucavado A. Skin pathology induced by snake venom metalloproteinase: acute damage, revascularization, and re-epithelization in a mouse ear model. J Invest Dermatol. 2008;128(10):2421-8.

15. Theakston RD, Reid HA. Development of simple standard assay procedures for the characterization of snake venom. Bull World Health Organ. 1983;61(6):949-56.

16. Junqueira LC, Montes GS, Sanchez EM. The influence of tissue section thickness on the study of collagen by the Picrosirius-polarization method. Histochemistry. 1982;74(1):153-6.

17. Telgenhoff D, Lam K, Ramsay S, Vasquez V, Villareal $\mathrm{K}$, Slusarewicz $\mathrm{P}$, et al. Influence of papain urea copper chlorophyllin on wound matrix remodeling. Wound Repair Regen. 2007;15(5):727-35.

18. Clark RA. Basics of cutaneous wound repair. J Dermatol Surg Oncol. 1993;19(8):693-706.

19. Stadelmann WK, Digenis AG, Tobin GR. Impediments to wound healing. Am J Surg. 1998;176(2A Suppl):39S47S.

20. Eming SA, Krieg T, Davidson JM. Inflammation in wound repair: molecular and cellular mechanisms. J Invest Dermatol. 2007;127(3):514-25.

21. Gutiérrez JM, Núñez J, Díaz C, Cintra AC, HomsiBrandeburgo MI, Giglio JR. Skeletal muscle degeneration and regeneration after injection of bothropstoxin-II, a phospholipase A2 isolated from the venom of the snake Bothrops jararacussu. Exp Mol Pathol. 1991;55(3):217-29.

22. Gutiérrez JM. Clinical toxicology of snakebite in Central America in Handbook of Clinical Toxicolgy of Animal Venoms and Poisons. In: Meier J, White J, editors. CRC Press: Boca Raton; 1995.

23. Teixeira C, Cury Y, Moreira V, Picolob G, Chaves F. Inflammation induced by Bothrops asper venom. Toxicon. 2009;54(7):988-97.

24. Weber A, Knop J, Maurer M. Pattern analysis of human cutaneous mast cell populations by total body surface mapping. Br J Dermatol. 2003;148(2):224-8.

25. Metcalfe DD, Baram D, Mekori YA. Mast cells. Physiol Rev. 1997;77(4):1033-79.

26. Maurer M, Theoharides T, Granstein RD, Bischoff SC, Bienenstock J, Henz B. What is the physiological function of mast cells? Exp Dermatol. 2003;12(6):886910.

27. Lewis RA, Austen KF. Mediation of local homeostasis and inflammation by leukotrienes and other mast celldependent compounds. Nature. 1981;293(5828):1038.

28. Paus R, Maurer M, Slominski A, Czarnetzki BM. Mast cell involvement in murine hair growth. Dev Biol. 1994;163(1):230-40.

29. Maurer M, Fischer E, Handjiski B, von Stebut E, Algermissen B, Bavandi A, et al. Activated skin mast cells are involved in murine hair follicle regression (catagen). Lab Invest. 1997;77(4):319-32. 
30. von Stebut E, Metz M, Milon G, Knop J, Maurer M. Early macrophage influx to sites of cutaneous granuloma formation is dependent on MIP-1alpha / beta released from neutrophils recruited by mast cellderived TNFalpha. Blood. 2003;101(1):210-5.

31. Weller K, Foitzik K, Paus R, Syska W, Maurer M. Mast cells are required for normal healing of skin wounds in mice. FASEB J. 2006;20(13):2366-8.
32. Biondo-Simões $\mathrm{M}$ de $\mathrm{L}$, Zimmermann $\mathrm{E}$, Daher TS, Borsato KS, de Noronha L. Effects of hormonal replacement therapy on colon anastomosis healing in rats. Acta Cir Bras. 2005;20(3):237-42.

33. Biondo-Simões M de L, Ioshii SO, Zazula AD, BiondoSimões R. The healing influenced by hypothyroidism and elderly. Study of intestinal anastomosis healing in rats. Acta Cir Bras. 2005;20(Suppl 1):204-10. 